possibility of various joint projects. Delegates attended from most of the Dominions and Colonial Territories and were shown around the various parts of the new headquarters and given information about research in the British Meteorological Office. A prototype of an auto. matic weather station was demonstrated in the instruments development branch, and special subjects, such as numerical weather prediction, the high atmosphere and agricultural meteorology, were discussed.

\section{Geological Photographs}

THE collection of photographs built up over many years by the Geological Survey of Great Britain has long been a source of illustrations for British and foreign literature on geology and physical geography. To facilitate the fuller use of this collection, a third edition of the catalogue has just been prepared (Classified Geological Photographs. Pp. 126. London: H.M.S.O., 1963. Price 7s.). This lists under appropriate headings particulars of some 2,300 selected black-and-white subjects, with a brief description of each. It should be useful to teachers and prospective authors in the earth sciences. A few $35-\mathrm{mm}$ colour transparencies, obtainable (price $1 s .6 d$. each) from the Geological Museum, London, S.W.7, are also listed; these illustrate mineral specimens and physiographic phenomena. A more extensive collection of coloured slides of this kind, chosen to depict the classical localities of British geology, would be warmly welcomed by educational institutions at home and overseas and would do much to encourage geological tourism. It is therefore pleasing to note a promise that "additional transparencies will be added from time to time".

\section{Radium-226 in Bone and Soft Tissues of Man}

Prof. J. B. Hursh has written to the Editor stating that Dr. C. R. Hill has directed his attention to the fact that in the discussion in the article "Radium-226 in Bone and Soft Tissues of Man" (Nature, 198, 265; 1963), Prof. Hursh and Mr. A. Lovaas inadvertently misquote results published in a paper by Prof. W. V. Mayneord on total a-activity (Clinical Radiology, 11, 2; 1960). In comparing results on "Human Muscle" listed in Fig. 6 (Mayneord's work) as $51.3 \times 10^{-14} \mathrm{c} / \mathrm{g}$ ash with "meat" Fig. 10 (Mayneord's work) at $0.5 \times 10^{-12} \mathrm{c} . / 100 \mathrm{~g}$, Prof. Hursh and Mr. Lovaas erroneously state that the value for meat is "only about 1 per cent of the value for "muscle"". Dr. Hill specifies that the "meat" value is in per $100 \mathrm{~g}$ (wet), and on re-examination of the data it is unambiguously clear that the set of food measurements in Fig. 10 (May. neord's work) specified as per $100 \mathrm{~g}$ constitutes the only concentration measurements in the presentation not labelled as per gram ash and should indeed be interpreted as Dr. Hill suggests. Therefore, the total $\alpha$-activity measurements for human muscle and for meat reported by Prof. Mayneord are in agreement, and the value of Prof. Hursh and Mr. Lovaas for radium-226 content of human muscle instead of being, as they state, nearly equivalent to the total $\alpha$-activity for meat, is in fact about 100 times lower.

\section{University News :}

Aberdeen

THE following appointments have been announced: Lectureships, Dr. E. R. Skinner (biological chemistry), Dr. G. P. McQuillan (chemistry), Mr. N. Milne (electrical engineering), Mr. C. M. Clapperton (geography), Miss S. Steigerwalt (mathematics), Dr. J. B. J. Wells (natural history), Dr. F. O. Goodman (natural philosophy), Mr. T. E. Evans (statistics), Dr. J. Annett (psychology). Imperial Chemical Industries Research Fellowships, Mr. J. A. Budd (biological chemistry), Dr. J. M. Hay (chemistry), Mr. S. Hart (natural philosophy).

THE following appointments to lectureships have been announced: Dr. D. H. Allcorn (sociology); Mr. J. Peel (sociology); Dr. G. W. Crosbie (biochemistry); Mr. R. G. Swinburne (philosophy); Dr. J. W. Thompson (mathematical statistics).

Keele

Mr. R. Harris, senior lecturer in charge of the Psychology Department, Borough Road College, has been appointed lecturer in education with effect from Septem. ber 1 ; Dr. H. H. Greenwood, at present working with Imperial Chemical Industries, Ltd., has been appointed computation director with effect from October 1 .

London

DR. D. R. Arthur, reader in zoology at King's College, has been appointed to the chair of zoology tenable at that College. Dr. I. D. P. Wootton, reador in chemical pathology at the Postgraduate Medical School of London, has boen appointed to the chair of chemical pathology tenable at that School. Dr. T. S. West, lecturer in analytical chemistry at the University of Birmingham, has been appointed to the readership in analytical chemistry tenable at the Imperial College of Science and Technology.

Nottingham

Dr. G. E. Lamming, at present reader in animal physiology in the Department of Agriculture, has been appointed professor of animal science from October 1. Mr. H. Davies, at present headmaster of High Pavement School, Bulwell, Nottingham, has been appointed director of the Institute of Education from September 1.

\section{Announcements}

Prof. A. R. Collar, professor of aeronautical engineering in the University of Bristol, has been elected president of the Royal Aeronautical Society for 1962-63. Prof. Collar succeeds Mr. B. S. Shenstone.

THE ninth quinquennial congress of the Universities of the British Commonwealth will be held in the University of London during July 15-19. Further information can be obtained from S. W. C. Holland, 36 Gordon Square, London, W.C.1.

A symposium on "Radiation Biology: the Biological Effects of Ionizing Radiation", sponsored by the University of Michigan, will be held in the University during July 8-10. Further information can be obtained from Prof. C. J. Shellabarger, 7691 Kresge MRB, University of Michigan, Ann Arbor.

A sxmposium for sixth-form science students, arranged by Watford College of Technology, will be held at the College on July 17. The programme will include: research and public safety; development of television. Further information can be obtained from R. H. Rogers, Department of Engineering, Watford College of Technology, Hempstead Road, Watford.

A Discussion on "Pharmaceutical Practice in Canada and Great Britain" will be held between pharmacists in Canada and Great Britain at 17 Bloomsbury Square, London, W.C.I, on June 18. The meeting is to be organized by the Pharmaceutical Society of Great Britain. Further information can be obtained from Mr. F. W. Thomas, the Pharmaceutical Society of Great Britain, 17 Bloomsbury Square, London, W.C.I.

AN Advanced Study Institute on "The Biliary System", sponsored by NATO, will be held in Newcastle upon Tyne during September 3-14. The Institute will be concerned with the anatomy, physiology, biochemistry and pathology of the biliary and related systems. Financial assistance is provided for 'student members' of the Institute. Further information can be obtained from the director, Dr. W. Taylor, NATO Advanced Study Institute, Depart. ment of Physiology, Medical School, King's College, Newcastle upon Tyne 1. 